\title{
Effect of adding different levels of red ginseng roots powder to feed on some physiological characteristics of Japanese quail (Coturnix japonica).
}

\author{
${ }^{1}$ Abdul Karim Mazid Al-Waeli , ${ }^{2}$ Khalid Chillab Kridie Al-Salhie \\ ${ }^{1,2}$ Department of Animal Production, College of Agriculture, University of Basrah, Basrah ,Iraq.
}

\begin{abstract}
The present study was conducted at in the Quail field of the Faculty of the Agriculture/University of Basrah for the period from $21 / 9 / 2017$ to $12 / 11 / 2017$ to determine the effect of adding different levels of red ginseng roots powder to feed on some physiological of the Japanese quail. A total of 240 Japanese quail birds aged one week were used in this study. The birds were randomly distributed into four treatments ( 60 birds for each). Each treatment was replicated three times (20 birds for each). (T1) fed a basal diet without feed additive (control), (T2), (T3), and (T4) were fed a basal diet with adding red ginseng roots powder 250,500 and $750 \mathrm{mg} / \mathrm{kg}$ respectively. The results indicated add the red ginseng roots powder has no significant differences between treatments on some blood characteristics (RBCs, PCV and $\mathrm{Hb}$ ) at 60 days of age in both male and female, while the T4 and T3 treatments were recorded highest value in WBCs and the lowest Value in $(\mathrm{H} / \mathrm{L})$ for both male and female compared with the $\mathrm{T} 2$ and $\mathrm{T} 1$. In conclusion, the red ginseng roots powder has a positive effect to improve the immune status of quails and reduce stress.
\end{abstract}

Key words: ginseng, physiological characteristics, Quail.

*This study is a part from thesis of first researcher.

\section{Introduction}

Due to economic development and rising living standards for citizens make a lot of countries around the world to find rich sources of nutrients which poultry products from meat and eggs, which are rich sources of animal protein, so the developed countries are working to provide these resources by raising the types Many birds such as ostrich, chicken and Japanese quail (Adeola, 2006). Japanese quail characterized many qualities, that distinguishes the meat taste special and delicious flavor is desirable for many consumers (Vali, 2008). It is also characterized by encouraging productive qualities and low breeding costs compared to the cost of raising chickens, high growth speed and early sexual maturity (Abu Al Ola, 2005). Medicinal plants have been used in poultry diets in various forms, including oil extracts, water or food additives to improve productivity and health status and reduce reliance on antibiotics(Greathead,2003). Ginseng is one of the basic part and perennials utilized is the root because it contains many nutrients like vitamins and minerals important to the human body and animal (Lee et al.,2013). As well as many active compounds which ginsenoside and polysaccharide and peptides and flavonoids (Kang et al, 2013). It has many medical uses and effects where used as a stimulating for most physiological characteristics as well as being an antioxidant (Kim et al.,2011).And it play a major role in stimulating the immune system (Ao et al.,2011).As well as its role in increasing productive poultry performance (Yildirim et al.,2013). Ao et al., (2011) showed to add red ginseng extract to broiler diets in $(1,2$ and $4 \mathrm{~g} / \mathrm{kg}$ ) led to an increase in lymphocytes cells. Yan et al., (2011) indicated through their study on broiler which was two days old that the addition of red ginseng roots of to feed in concentrations ( 0.1 and 0.2 and $0.3 \%$ ) did not effect on red blood cells (RBCs) compared to the control treatment while addition has appears high significant in the number of lymphocytes compared with the control 
treatment. The current study aimed to find out the impact of adding powdered of red ginseng roots to feed on some physiological characteristics of Japanese quail.

\section{Materials and Methods}

The current study was conducted in the Quail field of the Faculty of the Agriculture/University of Basrah for the period from $21 / 9 / 2017$ to $12 / 11 / 2017$.In this experiment, 240 birds of quail were used at the age of one week, and the birds were randomly distributed into four treatments, each treatment has 60 birds. Each treatment replicated three times (20 birds for each). The first treatment birds (control) were fed on basal diet, without an addition containing $20 \%$ crude protein and $2900 \mathrm{kcal} / \mathrm{kg}$ metabolism represented by (NRC, 1994) while the second, third and fourth treatment birds were fed to the control's diet and add the red ginseng root powder by $(250,500$ and $750 \mathrm{mg} / \mathrm{kg}$ feed) respectively.

Blood samples of birds were taken at 60 days of the bird's age from 3 males and 3 females of each treatment, and put in a container tube on the anticoagulant (EDTA) to estimate some blood parameter as the account of red blood cells (RBCs $10^{6}$ cell/ $\mathrm{ml}^{3}$ ), and hemoglobin concentration $(\mathrm{Hb} \mathrm{g} / 100 \mathrm{ml}$ ) and Packed cell volume (PCV\%) and White blood cells (WBCs $10^{3} / \mathrm{mm}^{3}$ ) and the ratio of heterophils/ lymphocytes (H/L\%). As calculating (RBCs) by applying the equation referred to by Natt and Herrik, (1952)، and white blood cells (WBCs) were calculated according to the equation as by mentioned (AL-Darraji et al., 2008). While in Packed cell volume (PCV\%) Using special centrifuge Micro-hematocrit centrifuge as indicated by (Archer, 1965), and using a Sahli device to calculate blood hemoglobin concentration $(\mathrm{Hb})$ according to the way (Schalm et al. 1975). The ratio of Heterophils / lymphocytes cells (H/L) was calculated according to the following equation: (Humason, 1972)

$(\mathrm{H} / \mathrm{L})=\frac{\text { Heterophils } / 100 \text { cells }}{\text { lymphocytes } / 100 \text { cells }}$

Collected data were subjected to one-way analysis of variance (ANOVA) and differences were considered to be significant if $P$ was $<0.05$ according to Statistics SPSS (2015) and statistical analysis by the mathematical model equation: $\mathrm{Yij}=\mathrm{M}+\mathrm{Ti}+\mathrm{Eij}$ as:

Yij: The value of the J view returned for the I treatment.

$M:$ the General average of the studied concept

Ti: Treatment effect I the study included four coefficients

EIJ: A random error that is distributed naturally with an average equal to 0 and a variation of $\sigma 2 e$.

\section{Results and Discussion}

The current study designed to evaluate adding 250,500 , and $750 \mathrm{mg} / \mathrm{kg}$ from red ginseng roots powder by adding to a nutrition that Japanese quail birds had feed. The study tested both genders of the Japanese quail birds. The results have no significant differences between treatments on the account of red blood cells, (RBCs $10^{6}$ cell/ $\mathrm{ml}^{3}$ ) hemoglobin concentration $(\mathrm{Hb} \mathrm{mg} / 100 \mathrm{ml}$ ) and packed cell volume (PCV\%) in both sexs bird in both males and females (Table:1). The study agrees with (Yan et al.,2011) who used 0.1, 0.2, and $0.3 \%$ of the same plant root powder mixed with the nutrition that meat chickens feed. Yan et al., (2011) showed that no significant different on the RBCs account of the birds compared with the control group. Also, the present study had the agreement with 
ISSN Onlin:2708-9347, ISSN Print: 2708-9339 Volume 9, Issue 1 (2020) PP 79-84

\section{https://jam.utq.edu.iq/index.php/main Doi: https://doi.org/10.54174/UTJagr.Vo10.N1/09}

(Kim et al., 2015) when they tested 0.5, 1, and 2\% of the same plant added to the nutrition of 76 week old chickens. Kim et al., (2015) referred that no significant effects on the $\mathrm{Hb}$ concentrations of the birds.

\begin{tabular}{|c|c|c|c|c|c|c|}
\hline & \multicolumn{3}{|c|}{ Male } & \multicolumn{3}{|c|}{ Female } \\
\hline Treatment & RBC & $\mathrm{HB}$ & PCV\% & RBC & $\mathrm{HB}$ & PCV\% \\
\hline T1 & $5.28 \pm 0.07$ & $14.08 \pm 0.20$ & $42.25 \pm 0.62$ & $3.87 \pm 0.16$ & $11.16 \pm 0.45$ & $35.00 \pm 1.35$ \\
\hline $\mathrm{T} 2$ & $5.34 \pm 0.15$ & $14.24 \pm 0.41$ & $42.75 \pm 1.25$ & $3.96 \pm 0.09$ & $11.41 \pm 0.25$ & $35.75 \pm 0.75$ \\
\hline T3 & $5.43 \pm 0.24$ & $14.50 \pm 0.64$ & $43.50 \pm 1.93$ & $4.03 \pm 0.10$ & $11.46 \pm 0.38$ & $36.25 \pm 0.85$ \\
\hline T4 & $5.46 \pm 0.30$ & $14.58 \pm 0.82$ & $43.75 \pm 2.46$ & $4.02 \pm 0.09$ & $11.58 \pm 0.25$ & $36.25 \pm 0.77$ \\
\hline Significant & N.S & N.S & N.S & N.S & N.S & N.S \\
\hline
\end{tabular}

Table 1 Effect of red ginseng roots powder on some blood parameter of male and female Japanese quail at the age of 60 days (mean \pm standard error)

T1-Control without any addition. T2 = Add the Red ginseng root powder with a concentration of $250 \mathrm{mg} / \mathrm{kg} \mathrm{feed}$. $\mathrm{T} 3$ = Add the Red ginseng root powder with a concentration of $500 \mathrm{mg} / \mathrm{kg}$ feed. $\mathrm{T} 4$ = Add the Red ginseng root powder with a concentration of $750 \mathrm{mg} / \mathrm{kg}$ feed.

Related to the effects of the tested plant (red ginseng roots powder), the 250,500 , and $750 \mathrm{mg} / \mathrm{kg}$ possessed the significant evidences $(P \leq 0.05)$ on the account white blood cells $(\mathrm{WBC})$ and ratio of heterophils to lymphocytes $(\mathrm{H} / \mathrm{L})$ in both males and females at days old birds. The significant effects recorded in the birds of third and fourth treatments, The males of the birds at fourth treatment had appeared $25.76\left(10^{3} / \mathrm{ml}^{3}\right)$ as a highest value in comparison with the control treatment, $17.15\left(10^{3} / \mathrm{ml}^{3}\right)$. In the females of the treatment, the values was 23.78 $\left(10^{3} / \mathrm{ml}^{3}\right)$ compared with the control treatment, $18.48\left(10^{3} / \mathrm{ml}^{3}\right)$ (Table:2). The results may be due to the increasing force of the bird immunity that taking the root powder of ginseng which led to make the immune cells increased against any immunogenic (Jensen et al., 2000; Kim et al., 2011). So, it may be said that the root powder represented as immunogenic agents in the bird blood that led to WBCs proliferated.

The results of the study showed a little value of the Heterophils to lymphocytes ratio (H/L) in which 0.24 recorded in bird males while 0.25 in the females of fourth treatment compared with the control treatment which was 0.78 noted in males, and 0.79 in the females. The results may be the explanation that is because the red 
ISSN Onlin:2708-9347, ISSN Print: 2708-9339 Volume 9, Issue 1 (2020) PP 79-84

\section{https://jam.utq.edu.iq/index.php/main Doi: https://doi.org/10.54174/UTJagr.Vo10.N1/09}

ginseng powder used as a regulator for the metabolic processes in the body. The regulation of the plant may be to make a body to be adapted against the stress factors that made the immunity to be forced against pathogens and immunogenic agents (Jang et al., 2007; Kim et al., 2011). Therefore, the third and fourth treatments gave a good immunity especially increasing lymphocyte cells due to adding root powder of red ginseng to birds nutrition. The results of the study agree with (Zhang et al., 2009; Ao et al., 2011) who showed to add red ginseng extract broiler diets in $(1,2$ and $4 \mathrm{~g} / \mathrm{kg})$ led to an increase in lymphocytes cells.

Table 2 Effect of red ginseng roots powder on white blood cell (WBC) $\left(10^{3} / \mathrm{mm}^{3}\right)$ and $\mathrm{H} / \mathrm{L}$ ratio in the blood of male and female Japanese quail at 60 days of age (mean \pm standard error)

\begin{tabular}{|c|c|c|c|c|}
\hline \multirow[b]{2}{*}{ Treat meant } & \multicolumn{2}{|c|}{ Male } & \multicolumn{2}{|c|}{ Female } \\
\hline & WBC & $H \backslash \mathrm{L}$ & WBC & $\mathrm{H} \backslash \mathrm{L}$ \\
\hline \multicolumn{5}{|l|}{ T1 } \\
\hline & 17.15 c \pm 0.65 & $0.78 a \pm 0.035$ & $18.48 c \pm 0.66$ & $0.79 a \pm 0.066$ \\
\hline \multicolumn{5}{|l|}{ T2 } \\
\hline & $19.14 b c \pm 0.86$ & $0.65 a \pm 0.072$ & $20.46 b c \pm 1.43$ & $0.70 \mathrm{a} \pm 0.073$ \\
\hline \multicolumn{5}{|l|}{ T3 } \\
\hline & $22.78 a b \pm 1.50$ & $0.29 b \pm 0.008$ & $21.80 a b \pm 0.58$ & $0.33 b \pm 0.023$ \\
\hline \multirow[t]{2}{*}{ T4 } & & & & \\
\hline & 25.76 a \pm 2.26 & $0.24 b \pm 0.016$ & 23.78 a \pm 0.56 & $0.25 b \pm 0.021$ \\
\hline
\end{tabular}


ISSN Onlin:2708-9347, ISSN Print: 2708-9339 Volume 9, Issue 1 (2020) PP 79-84

https://jam.utq.edu.iq/index.php/main Doi: https://doi.org/10.54174/UTJagr.Vo10.N1/09

\begin{tabular}{|l|l|l|l|l|}
\hline Significant & $*$ & $*$ & $*$ & $*$ \\
\hline
\end{tabular}

* Different characters mean there are differences between treatments.

T1-Control without any addition. T2 = Add the Red ginseng root powder with a concentration of $250 \mathrm{mg} / \mathrm{kg}$ feed. $\mathrm{T} 3$ = Add the Red ginseng root powder with a concentration of $500 \mathrm{mg} / \mathrm{kg}$ feed. $\mathrm{T} 4$ = Add the Red ginseng root powder with a concentration of $750 \mathrm{mg} / \mathrm{kg}$ feed.

\section{Conclusions}

The current study concluded that the red ginseng roots powder possesses an ability to increase the Japanese quail birds immune cells when the root powder is given with their diet. Additionally, the powder of red ginseng roots can decrease the stress of the birds.

\section{References}

1 Abu al-Ola, Salah al-Din. (2005). Quail-breeding-care-nutrition-projects. First edition, Faculty of Agriculture - Zagazig University.

2 Adeola, O., (2006). Review of research in duck nutrient Utilization. Animal Science Papers and Reports vol. 24 : ( 3$) ; 259-266$.

3 Al-Darraji, Hazem Jabbar al-Hayani, Walid Khaled and Al-Hassani, Ali Sabah (2008). The blood Physiology of the birds. Ministry of Higher Education and scientific research/Faculty of Agriculture/University of Baghdad.

4 Ao, X., Zhou, T.X., Kim, H.J., Hong, S.M. and Kim, I.H., (2011).Influence of fermented Red Ginseng extract on broilers and laying hens. Asian- Aust. J. Anim. Sci. 24, 993-1000.

5 Archer, R. K. (1965). In Haematological techniques Jor use in animals. Appendix I, pp. 119-121. Oxford: Blackwell.

6 Greathead, H. (2003). Plants and plant extracts for improving animal productivity. Proc. Nutr.Soc., 62:279290.

7 Humason, G.L. (1972). Animal tissue techniques 3rd ed. Freeman and Company-San Francisco, Ca. pp230.

8 Jang, H. D., Kim, H. J., Cho, J. H., Chen, Y. J., Yoo, J. S., Min, B. J., and Kim, I. H. (2007). Effects of dietary supplementation of fermented wild-ginseng culture by-products on egg productivity, egg quality, blood characteristics and ginsenoside concentration of yolk in laying hens. Korean Journal of Poultry Science.278-271:(4)34, 
9 Jensen, G. S., Ginsberg, D. I., Huerta, P., Citton, M., and Drapeau, C. (2000). Consumption of Aphanizomenon flos-aquae has rapid effects on the circulation and function of immune cells in humans. Journal of the American Nutraceutical Association.58-50:2 ,

10 Kang, K. S., Ham, J., Kim, Y. J., Park, J. H., Cho, E. J., and Yamabe, N. (2013). Heat-processed Panax ginseng and diabetic renal damage: active components and action mechanism. Journal of ginseng research,37(4),379.

11 Kim, H.G., Yoo, S.R., Park, H.J., Lee, N.H., Shin, J.W., Sathyanath, R., Cho, J.H. and Son, C.G., (2011). Antioxidant effects of Panax ginseng C.A. Meyer in healthy subjects: A randomized, placebocontrolledclinical trial. Food Chem. Toxicol. 49, 2229-2235.

12 Kim, Y. J., Lee, G. D., and Choi, I. H. (2015). Effects of dietary red ginseng marc on egg production, egg quality and blood characteristics of laying hens. Journal of Applied Animal Research.246-242;(2)43 ,

13 Lee, D. H., Cho, H. J., Kim, H. H., Rhee, M. H., Ryu, J. H., and Park, H. J. (2013). Inhibitory effects of total saponin from Korean red ginseng via vasodilator-stimulated phosphoprotein-Ser157 phosphorylation on thrombin-induced platelet aggregation. Journal of ginseng research, 37(2), 176.

14 Natt, M. P. and Herrick, C. A. (1952). A new blood diluent for counting the erythrocytes and leucocytes of the chicken. Journal of Poultry Science, 31: 735-738.

15 NRC (National Research Council). 1994. Nutrient Requirements of Poultry. 9th Rev. Ed. National Academy Press. Washington, DC. 176 Pages.

16 Schalm, O. W., Jain, N. C., and Carroll, E. J. (1975). Veterinary hematology (No. 3rd edition). Lea and Febiger.

17 SPSS, Statistical Package for the Social Sciences (2015). Quantitative Data Analysis with IBM SPSS version 23: A Guide for Social Scientists. New York: Routledge. ISBN 978-0-415-57918-6

18 Vali ,N .(2008) The Japanese quail : A Review .International Journal of Poultry science 7 (9) : 925-931.

19 Yan, L., Meng, Q. W., Lee, J. H., Wang, J. P., and Kim, I. H. (2011). Effects of dietary wild-ginseng adventitious root meal on growth performance, blood profiles, relative organ weight and meat quality in broilerchickens. Asian-Australasian Journal of Animal ciences.263-258;(2)24 ,

20 Yildirim, A., Sen, M. I., Sekeroglu, A., and Eleroglu, H. (2013). Effects of Korean ginseng (Panax ginseng CA Meyer) root extract on egg production performance and egg quality of laying hens. South African Journal of Animal Science, 43(2); 194-207.

21 Zhang, X., Yu, L., Bi, H., Li, X., Ni, W., Han, H., ... and Tsai, G. (2009). Total fractionation and characterization of the water-soluble polysaccharides isolated from Panax ginseng CA Meyer. Carbohydrate Polymers, 77(3): 544-552. 